\title{
Efficiency of the training process in dance sport athletes at the comprehensive stage of training
}

\author{
Authors' Contribution: \\ A Study Design \\ B Data Collection \\ C Statistical Analysis \\ D Data Interpretation \\ E Manuscript Preparation \\ F Literature Search \\ G Funds Collection
}

\author{
Agnieszka Zabrocka ABCEFG, Tomasz Dancewicz CD, \\ Agnieszka Supinska ABEFG
}

Gdansk University of Physical Education and Sport in Gdansk, Poland

abstract

Background The research aimed to determine motor skills that significantly affect the level of technical preparation in dancesport at the early stage of training. The applicable purpose was to determine the selection indicators in dancesport at the stage of initial training.

Material/Methods

The study involved 50 dancesport contestants aged 6-9 years. The tests were carried out 3 times, at the beginning, after a year and after two years of training. Motor skills were assessed by means of: the Starosta's test, a stabilographic platform, the IPTF trial, a trial testing the frequency of moves, a measurement of explosive strength of the lower limbs, ergometric measuring equipment "Concept 2 Dyno", a test of simple reaction speed and of anticipation in space. Special fitness was determined on the basis of results of special fitness tests and standard anthropometric measurements were made by means of Martin's method. A factor analysis was made of all the measurements; the correlation matrix was calculated with probability at $p \leq 0.05$. Independent variables were confronted with the special fitness test results presented by the studied dancers. The multiple regression method was used, and for analysis the special fitness test result of 3 dance tournaments immediately after the 1st, 2nd and 3rd stage of laboratory tests and the results of these tests were taken.

Results The result of the special fitness test at the 1st stage of research is explained by multiple regression with independent variables in $66 \%$, at the 2 nd stage of research in $87 \%$, and at the 3 rd stage of research in $81 \%$. The highest level of regression was reported at the 1 st stage of research for the variable both legs coordination and at the 3rd stage of research for the variables balance and chené turns.

Conclusions 1. At the early stage of practicing dancesport, the greatest impact on the special fitness is exerted by: motor coordination, balance, flexibility, speed and strength skills, the body height and mass, the pelvis, torso, and chest indicators, and BMI. 2 . The tests and indices applied in the research best reflect the specificity of dancesport and they can be recommended in the selection process for this sport discipline.

Key words dancesport, effectiveness of training, motor skills.

\section{article details}

Article statistics

Full-text PDF:

Copyright

Indexation:

Funding:

Competing interests: Corresponding author:

Open Access License:
Word count: 3382; Tables: 6; Figures: 11; References: 14

Received: September 2014; Accepted: January 2015; Published: March 2015

http://www.balticsportscience.com

() Gdansk University of Physical Education and Sport, Poland

Celdes, CNKI Scholar (China National Knowledge Infrastructure), CNPIEC, De Gruyter - IBR (International Bibliography of Reviews of Scholarly Literature in the Humanities and Social Sciences), De Gruyter - IBZ (International Bibliography of Periodical Literature in the Humanities and Social Sciences), DOA], EBSCO - Central \& Eastern European Academic Source, EBSCO - SPORTDiscus, EBSCO Discovery Service, Google Scholar, Index Copernicus, J-Gate, Naviga (Softweco, Primo Central (ExLibris), ProQuest - Family Health, ProQuest - Health \& Medical Complete, ProQuest - Illustrata: Health Sciences, ProQuest - Nursing \& Allied Health Source, Summon (Serials Solutions/ProQuest, TDOne (TDNet), Ulrich's Periodicals Directory/ulrichsweb, WorldCat (OCLC) Authors' own sources.

Author has declared that no competing interest exists.

Dr Agnieszka Zabrocka, Gdansk University of Physical Education and Sport, K. Górskiego St. 1, 80-336 Gdansk, Poland

Phone: 4858 554- 72-05, e-mail: agazabrocka@wp.pl

This is an open access article distributed under the terms of the Creative Commons Attribution-Non-commercial 4.0 International (http://creativecommons.org/licenses/by-nc/4.0/), which permits use, distribution, and reproduction in any medium, provided the original work is properly cited, the use is non-commercial and is otherwise in compliance with the license. 


\section{INTRODUCTION}

Dancesport belongs to acyclic disciplines with high volume and diversity of motor tasks, in which there is early specialization. To practice dancesport, one needs a high level of motor coordination. This discipline requires a complex technique, aesthetics and, above all, the ability to perform movements and choreographic routines in accordance with the rhythm of music [1]. Professional sport imposes high demands on athletes, and only those succeed who have predispositions needed for a particular discipline. Selection of young athletes is a significant problem which should be handled comprehensively and in stages [2, 3].

The present research aimed to determine motor skills that significantly affect the level of technical preparation in dancesport at an early stage of training. The applicable purpose was to determine the selection indicators in dancesport at the stage of initial training.

\section{MATERIALS AND METHODS}

The study involved 50 dancesport contestants aged 6-9 years. The tests were carried out three times, at the beginning of training, after a year and after two years of training. To assess particular motor skills, the following tests were used. To assess the level of motor coordination, Starosta's test was used [4]. Balance was tested with a use of a stabilographic platform (the so-called posturograph). To determine the level of flexibility, a trial from the International Physical Fitness Test (IPFT) for people from aged 6 to 32 years was used [5]. Speed and strength skills were studied in two trials that take into account the specificity of the discipline of dancesport - a trial testing the frequency of movements and the measurement of explosive strength of the lower limbs. To assess the level of strength abilities, ergometric measuring apparatus "Concept 2 Dyno" was used. The speed of motor reaction to visual and auditory stimuli was studied using the tests of simple reaction and of anticipation in space. Special performance was determined on the basis of the results of a special fitness test. Two circles with a diameter of $30 \mathrm{~cm}$ and 5 metres away from each other were draw on the dance floor. The task was to move twice from one circle to the other (in both directions) through the execution of 8 "chené" turns, within a given rhythm (in the time signature 2/4, tempo 40 beats per min.). 5 components affected the task assessment: maintaining the specified rhythm, technique of arms and head work, maintaining the posture, keeping the direction, use of space, footwork technique. The evaluation was made using a test card and a point scale from 5 to 20 points. From among the basic coordination skills, the ability to perform turns requires: maintaining balance, spatial-temporal orientation, rhythmization, and the kinaesthetic differentiation of movement. The evaluation of the performance of the test is influenced by: the legs, trunk, arms and head work, precision and harmony of movement, feeling time, and focusing attention [6]. In order to determine the specificity of dancers' body composition, standard anthropometric measurements with Martin's method were made: measurement of body weight as well as length, width and circumference measurements. On the basis of these measurements, body composition indices were calculated.

In this paper, a factor analysis was made of all the measurements, and the correlation matrix was calculated with probability at $\mathrm{p} \leq 0.05$. Related factors 
were grouped, and where a significant correlation was found, only one variable representing the group was taken for the multivariate analysis; for example, variables of dynamic strength, work, speed, load for the right leg, the left leg and both legs were highly correlated with the variable both legs dyno max, so the whole group was represented by the variable both legs dyno max, and this factor was used in multiple regression. Other variables representing groups of coordination, speed and strength (physical), psycho-somatic, and body composition factors were selected in a similar way. Independent variables were confronted with the result of a special fitness test (Rokita's test) presented by the studied dancers.

For this purpose, the multiple regression method, which studies relationships between multiple independent variables (explanatory, predictors) and a dependent variable (criterial, explanatory), was used. Special fitness test results (a dependent variable) from three dance tournaments immediately after the 1 st, the 2 nd and the 3rd stage of laboratory tests and the results of these tests (independent variables) were taken for analysis.

\section{RESULTS}

Table 1. An analysis of correlation between independent variables with the Special Fitness Test in dancers at the 1st stage of research

\begin{tabular}{ll} 
Independent variables & $\begin{array}{c}\text { Special Fitness Test } 66 \% \\
\left(R^{2}=0.31820484\right. \\
\mathrm{p}=0.078680)\end{array}$ \\
\hline Both legs coordination & -0.4 \\
\hline Flexibility & 0.11 \\
\hline Dynamic strength of lower limbs & 0.1 \\
\hline Explosive strength & 0.05 \\
\hline Chené turns & -0.04 \\
\hline Simple reaction speed & -0.02 \\
\hline Anticipation reaction speed & -0.12 \\
\hline Balance with eyes open & -0.26 \\
\hline Body height & 0.06 \\
\hline Body weight & -0.09 \\
\hline Trunk indicator & 0.02 \\
\hline Pelvis indicator & -0.23 \\
\hline
\end{tabular}

Table 1 shows the result of multiple regression in dancers at the 1st stage of research. The result of the special fitness test at the 1st stage of research is explained in $66 \%$ by means of multiple regression with independent variables: flexibility, both legs coordination (Starosta's test), dynamic strength of lower limbs (dyno max total), explosive strength of lower limbs, chené turns (frequency of movements), speed of simple reaction and anticipation in space, body height and weight, keeping balance with eyes open, the field parameter, keeping balance with feedback, coordination parameter, and the trunk and pelvis indicators. Both legs coordination is the key variable amounting to -0.40 , which correlates in a statistically significant way with the result of the special fitness test at the level of $\mathrm{R}^{2}=0.318$, at $\mathrm{p}=0.0786$. 
Table 2. An analysis of correlation between independent variables with the Special Fitness Test in dancers at the 2 nd stage of research

\begin{tabular}{ll} 
Independent variables & $\begin{array}{c}\text { Special Fitness Test 87\% } \\
\left(R^{2}=0.25108873\right. \\
\mathrm{p}=0.177008)\end{array}$ \\
\hline Both legs coordination & -0.12 \\
\hline Flexibility & 0.01 \\
\hline Dynamic strength of lower limbs & 0.14 \\
\hline Explosive strength & 0.11 \\
\hline Chené turns & -0.25 \\
\hline Simple reaction speed & -0.05 \\
\hline Anticipation reaction speed & -0.1 \\
\hline Balance with eyes open & 0.17 \\
\hline Chest indicator & 0.22 \\
\hline Trunk indicator & -0.15 \\
\hline Pelvis indicator & 0.08 \\
\hline
\end{tabular}

Table 2 shows the result of multiple regression in dancers at the 2 nd stage of the research. The result of the special fitness test at the 2 nd stage of the research is explained in $87 \%$ by means of multiple regression with independent variables: flexibility, both legs coordination (Starosta's test), dynamic strength of lower limbs (dyno max total), explosive strength of lower limbs, chené turns (frequency of movements), speed of simple reaction and of anticipation in space, ability to maintain balance with eyes open, the field parameter, the trunk, pelvis and chest indicators. None of the above variables correlates in a statistically significant way with the score of the special fitness test. The independent variable, chené turns, correlates the most with the test results, with the value of 0.25 at the level of $\mathrm{R}^{2}=0.251$, at $\mathrm{p}=0.177$.

Table 3. An analysis of correlation between independent variables with the Special Fitness Test in dancers at the 3 rd stage of research

\begin{tabular}{ll} 
Independent variables & $\begin{array}{l}\text { Special Fitness Test 81\% } \\
\left(\mathrm{R}^{2}=0.17064491\right. \\
\mathrm{p}=0.113325)\end{array}$ \\
\hline Keeping balance with feedback, coordination parameter & 0.04 \\
\hline Dynamic strength of lower limbs & 0.15 \\
\hline Chené turns & -0.29 \\
\hline Balance with eyes open & 0.34 \\
\hline Trunk indicator & 0.08 \\
\hline BMI & -0.15 \\
\hline
\end{tabular}

Table 3 shows the result of multiple regression in dancers at the 3rd stage of the research. The result of the special fitness test at the 3rd stage of the research is explained in $81 \%$ by means of multiple regression with independent variables: dynamic force of the lower limbs (dyno max total), chené turns (frequency of movements), the ability to maintain balance with eyes open, the field parameter, the ability to maintain balance with feedback, the coordination parameter, the trunk indi-cators and BMI. The key variables are: chené turns, equal to 0.29 , and balance with eyes open, the field parameter, equal to 0.336 , which correlate with the score of the special fitness test at a statisti-cally significant level of $R^{2}=0.170$, with $p=0.113$. 
After an analysis conducted with statistical methods, namely multiple regression, one can notice that the highest level of regression was reported at the 1st stage of research for the variable both legs coordination and at the 3rd stage of research for the variables balance and chené turns. This gives us information that motor skills, such as coordination and body balance and technical skills needed to perform chené turns substantially influence the level of technical preparation in dances-port at this stage of sports proficiency.

In order to determine interdependence between the characteristics of somatic composition, motor skills and abilities, and psychophysical traits, a correlation analysis was applied between the particular variables. Table 4 shows the correlations between dependent variables in dancers at the 1st stage of the research. Figure 1 presents the results of research at the 1st stage, which showed statistically significant correlations between the variable both legs coordination and other variables. It was found that the higher the coordination (Starosta's test), the lesser the muscle strength of the lower limbs, the better the level of strength and speed capabilities in the trial of 8 chené turns (0.307), the lower the body height (-0.526), the smaller the body circumferences (-0.643), and the higher the speed of simple reaction (0.278).

Table 4. Correlations between dependent variables in dancers at the 1st stage of research

\begin{tabular}{|c|c|c|c|c|c|c|c|c|}
\hline Indicators & $\begin{array}{l}\text { Both } \\
\text { legs } \\
\text { coordi- } \\
\text { nation }\end{array}$ & $\begin{array}{l}\text { Dyno } \\
\text { Max R }\end{array}$ & $\begin{array}{l}\text { Chené } \\
\text { turns (s) }\end{array}$ & $\begin{array}{l}\text { Simple } \\
\text { reaction } \\
\text { speed }\end{array}$ & $\begin{array}{l}\text { Body } \\
\text { height }\end{array}$ & $\begin{array}{l}\text { Body } \\
\text { mass }\end{array}$ & $\begin{array}{l}\text { Pelvis } \\
\text { circum- } \\
\text { ference }\end{array}$ & Balance \\
\hline $\begin{array}{l}\text { Both legs } \\
\text { coordination }\end{array}$ & 1.000 & -0.199 & 0.307 & 0.278 & -0.526 & -0.218 & -0.644 & 0.136 \\
\hline $\begin{array}{l}\text { Dyno } \\
\text { Max R }\end{array}$ & -0.199 & 1.000 & -0.073 & -0.135 & 0.215 & 0.248 & 0.322 & -0.083 \\
\hline $\begin{array}{l}\text { Chené turns } \\
\text { (s) }\end{array}$ & 0.307 & -0.073 & 1.000 & 0.127 & -0.037 & -0.003 & -0.204 & -0.032 \\
\hline $\begin{array}{l}\text { Simple } \\
\text { reaction speed }\end{array}$ & 0.278 & -0.135 & 0.127 & 1.000 & -0.218 & -0.322 & -0.261 & -0.061 \\
\hline Body height & -0.526 & 0.215 & -0.037 & -0.218 & 1.000 & 0.457 & 0.750 & -0.304 \\
\hline Body mass & -0.218 & 0.248 & -0.003 & -0.322 & 0.457 & 1.000 & 0.533 & -0.174 \\
\hline $\begin{array}{l}\text { Pelvis } \\
\text { circumference }\end{array}$ & -0.644 & 0.322 & -0.204 & -0.261 & 0.750 & 0.533 & 1.000 & -0.239 \\
\hline Balance & 0.136 & -0.083 & -0.032 & -0.061 & -0.304 & -0.174 & -0.239 & 1.000 \\
\hline
\end{tabular}

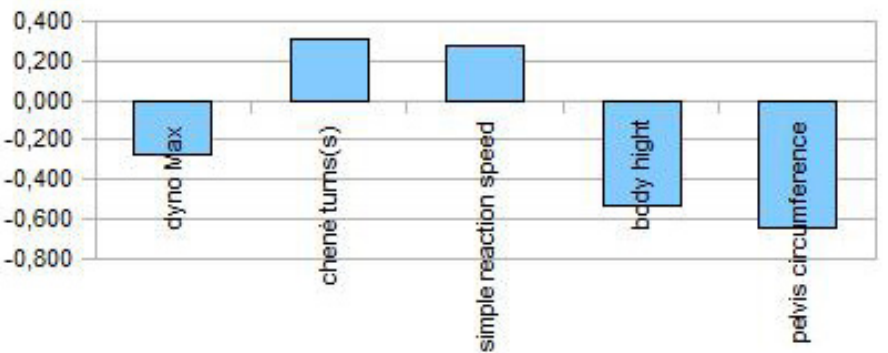

$\square$ both legs coordination

Fig 1. The correlation between the both legs coordination and the dynamic strength, technical skills, simple reac-tion speed, body height and the pelvis circumference in dancers at the 1st stage of research 
In addition, it was noted that the smaller the body weight (-0.321), the higher the speed of simple reaction $(-0.322)$ and the lesser the muscle strength of lower limbs (0.248) (Fig. 2).

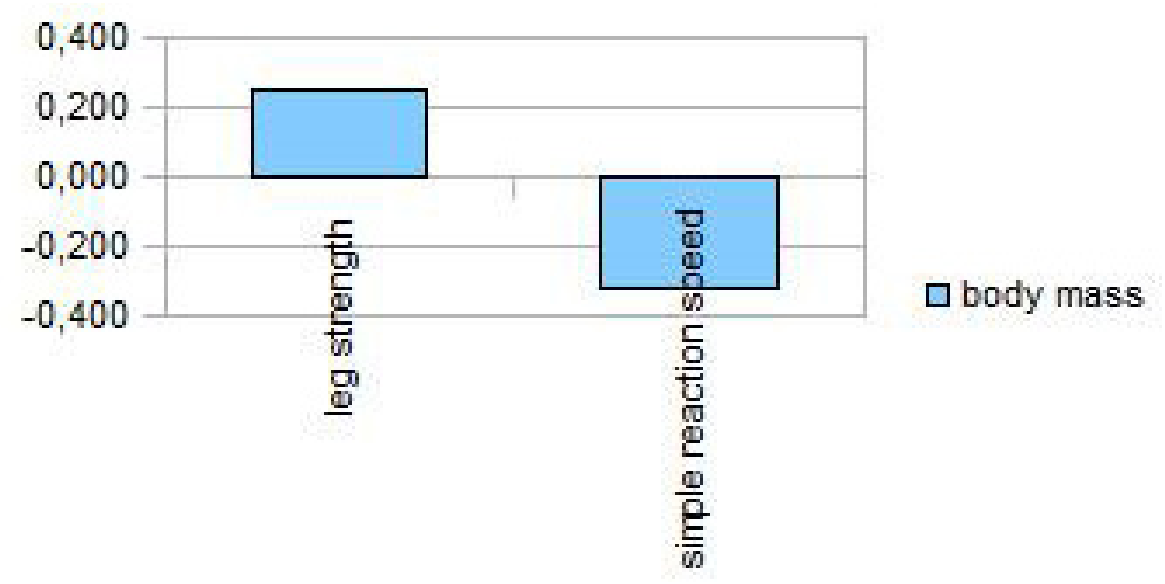

Fig 2. The correlation between body weight and the leg strength and the speed of simple reaction in dancers at the 1 st stage of research

The greater the body height, the greater the muscle strength of the lower limbs (0.215) and the lesser the balance (-0.304) (Fig. 3).

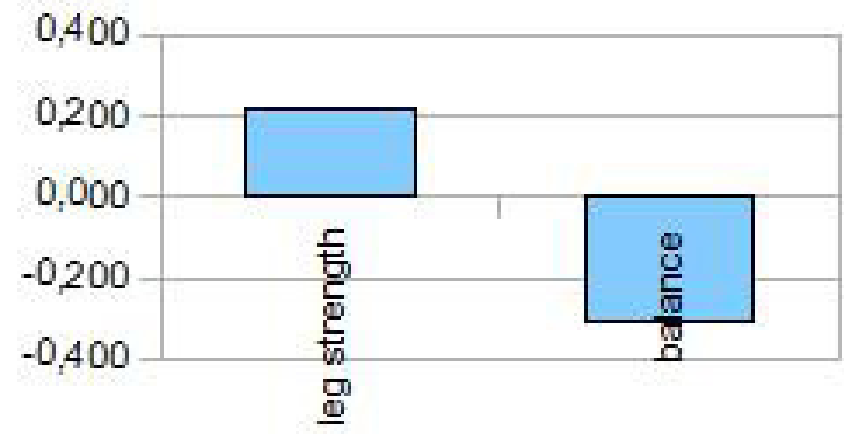

body height

Fig 3. The correlation between the body height and the strength of the lower limbs and balance in dancers at the 1st stage of research

Table 5 presents correlations between dependent variables in dancers at the 2nd stage of re-search. The results revealed statistically significant relationships between many variables. The level of coordination determined by means of Starosta's test correlates with Rohrer's index (0.457), BMI (0.340) and flexibility (0.267). An inverse correlation can be noted between coordination and the body height (-0.551) and mass (-0.175) and circumferences (-0.540) (Fig. 4).

The better the body balance, the higher the level of strength and speed capabilities in a trial of 8 chené turns (0.412) (Fig. 5). 
Table 5. Correlations between dependent variables in dancers at the 2 nd stage of the research

\begin{tabular}{|c|c|c|c|c|c|c|c|c|c|}
\hline Indicators & Flexibility & $\begin{array}{l}\text { Both } \\
\text { legs } \\
\text { coordi- } \\
\text { nation }\end{array}$ & $\begin{array}{l}\text { Chené } \\
\text { turns } \\
\text { (s) }\end{array}$ & $\begin{array}{l}\text { Body } \\
\text { height }\end{array}$ & $\begin{array}{l}\text { Body } \\
\text { mass }\end{array}$ & $\begin{array}{l}\text { Pelvis } \\
\text { circumfe- } \\
\text { rence }\end{array}$ & Balance & $\begin{array}{l}\text { Rohrer's } \\
\text { index }\end{array}$ & $\mathrm{BMI}$ \\
\hline Flexibility & 1.000 & 0.267 & -0.008 & -0.102 & -0.164 & -0.399 & 0.075 & 0.035 & -0.030 \\
\hline $\begin{array}{l}\text { Both legs } \\
\text { coordi- } \\
\text { nation }\end{array}$ & 0.267 & 1.000 & 0.237 & -0.551 & -0.175 & -0.540 & 0.035 & 0.457 & 0.340 \\
\hline $\begin{array}{l}\text { Chené } \\
\text { turns (s) }\end{array}$ & -0.008 & 0.237 & 1.000 & -0.088 & -0.080 & -0.327 & 0.412 & 0.037 & 0.009 \\
\hline $\begin{array}{l}\text { Body } \\
\text { height }\end{array}$ & -0.102 & -0.551 & -0.088 & 1.000 & 0.419 & 0.677 & -0.158 & -0.772 & -0.520 \\
\hline $\begin{array}{l}\text { Body } \\
\text { mass }\end{array}$ & -0.164 & -0.175 & -0.080 & 0.419 & 1.000 & 0.488 & 0.022 & 0.238 & 0.552 \\
\hline $\begin{array}{l}\text { Pelvis } \\
\text { circumfe- } \\
\text { rence }\end{array}$ & -0.399 & -0.540 & -0.327 & 0.677 & 0.488 & 1.000 & -0.287 & -0.394 & -0.173 \\
\hline Balance & 0.075 & 0.035 & -0.412 & -0.158 & 0.022 & -0.287 & 1.000 & 0.186 & 0.169 \\
\hline $\begin{array}{l}\text { Rohrer's } \\
\text { index }\end{array}$ & 0.035 & 0.457 & 0.037 & -0.772 & 0.238 & -0.394 & 0.186 & 1.000 & 0.940 \\
\hline BMI & -0.030 & 0.340 & 0.009 & -0.520 & 0.552 & -0.173 & 0.169 & 0.940 & 1.000 \\
\hline
\end{tabular}

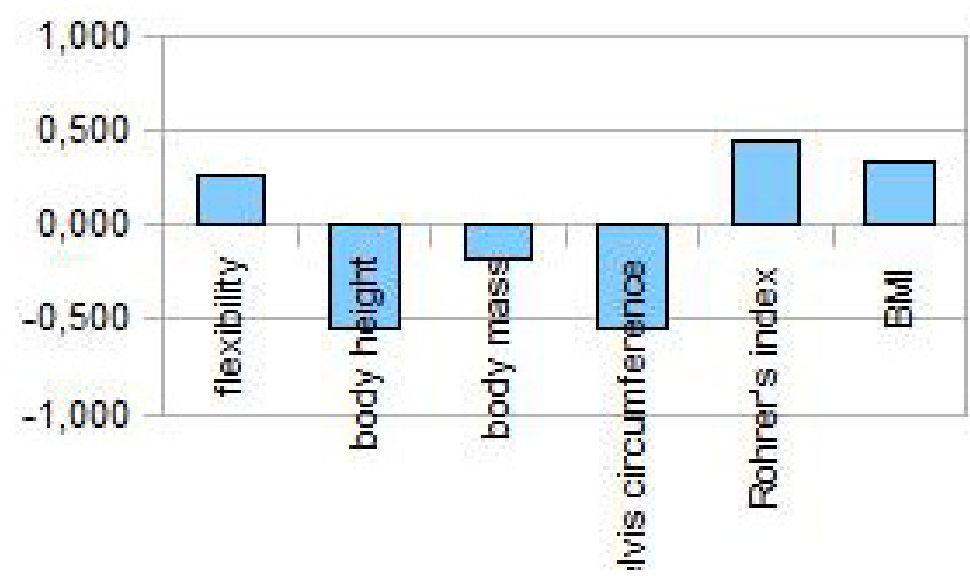

$\square$ both leg:

Fig 4. The correlation between both legs coordination and flexibility, body height and mass, pelvis circumference, Rohrer's index and BMI in dancers at the 2 nd stage of research 


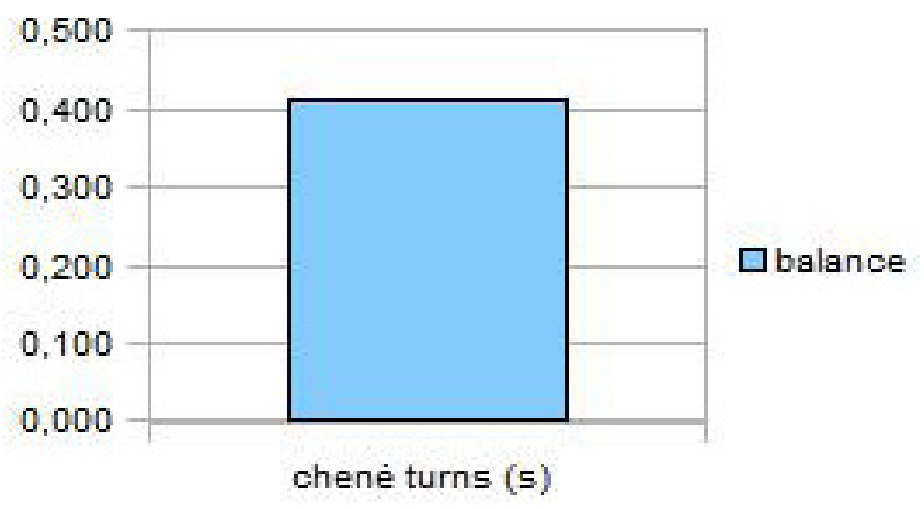

Fig 5. The correlation between balance and strength and speed capabilities in dancers at the 2 nd stage of research

Table 6 shows the correlations between dependent variables in dancers at the 3rd stage of research. At the third stage statistically significant relationships of the study results were revealed between many variables.

\begin{tabular}{|c|c|c|c|c|c|c|c|c|c|c|c|c|}
\hline Indicator & Flexibility & $\begin{array}{l}\text { Both legs } \\
\text { coordi- } \\
\text { nation }\end{array}$ & $\begin{array}{l}\text { One leg } \\
\text { coordi- } \\
\text { nation }\end{array}$ & $\begin{array}{l}\text { Dyno } \\
\text { Max R }\end{array}$ & $\begin{array}{l}\text { Chené } \\
\text { turns (s) }\end{array}$ & $\begin{array}{l}\text { Simple } \\
\text { reaction } \\
\text { speed }\end{array}$ & $\begin{array}{l}\text { Body } \\
\text { height }\end{array}$ & Body mass & $\begin{array}{l}\text { Pelvis } \\
\text { circumfe- } \\
\text { rence }\end{array}$ & $\begin{array}{l}\text { Balance } \\
\text { eyes open }\end{array}$ & $\begin{array}{l}\text { Balance } \\
\text { eyes } \\
\text { closed }\end{array}$ & $\begin{array}{l}\text { Rohrer's } \\
\text { index }\end{array}$ \\
\hline Flexibility & 1.000000 & 0.172109 & 0.381303 & -0.263941 & 0.061631 & 0.021397 & -0.189800 & -0.220501 & -0.503243 & 0.149248 & 0.009301 & 0.110829 \\
\hline $\begin{array}{l}\text { Both legs } \\
\text { coordi-- } \\
\text { nation }\end{array}$ & 0.172109 & 1.000000 & 0.489780 & -0.056064 & 0.075602 & 0.260216 & -0.391930 & -0.170193 & -0.406558 & 0.006592 & -0.052242 & 0.324645 \\
\hline $\begin{array}{l}\text { One leg } \\
\text { coordi- } \\
\text { nation }\end{array}$ & 0.381303 & 0.489780 & 1.000000 & 0.010257 & 0.391198 & 0.246595 & -0.317263 & -0.530316 & -0.530316 & -0.005522 & 0.004239 & 0.201906 \\
\hline $\begin{array}{l}\text { Dyno } \\
\text { Max R }\end{array}$ & -0.263941 & -0.056064 & 0.010257 & 1.000000 & -0.101821 & -0.152959 & 0.184617 & 0.281278 & 0.328082 & -0.314895 & -0.172518 & -0.008992 \\
\hline $\begin{array}{l}\text { Chené } \\
\text { turns (s) }\end{array}$ & 0.061631 & 0.075602 & 0.391198 & -0.101821 & 1.000000 & 0.123930 & -0.069835 & -0.056420 & -0.310307 & 0.201937 & 0.298228 & 0.036733 \\
\hline $\begin{array}{l}\text { Simple } \\
\text { reaction } \\
\text { speed }\end{array}$ & 0.021397 & 0.260216 & 0.246595 & -0.152959 & 0.123930 & 1.000000 & -0.354492 & -0.384814 & -0.308088 & 0.249226 & 0.131217 & 0.192926 \\
\hline $\begin{array}{l}\text { Body } \\
\text { height }\end{array}$ & -0.189800 & -0.391930 & -0.353071 & 0.184617 & -0.069835 & -0.354492 & 1.000000 & 0.381668 & 0.588300 & -0.208302 & -0.134117 & -0.844418 \\
\hline Body mass & -0.220501 & -0.170193 & -0.317263 & 0.281278 & -0.056420 & -0.384814 & 0.381668 & 1.000000 & 0.467376 & -0.151328 & 0.021624 & 0.156256 \\
\hline $\begin{array}{l}\text { Pelvis } \\
\text { circumfe- } \\
\text { rence }\end{array}$ & -0.503243 & -0.406558 & -0.530316 & 0.328082 & -0.310307 & -0.308088 & 0.588300 & 0.467376 & 1.000000 & -0.346078 & -0.290715 & -0.371321 \\
\hline $\begin{array}{l}\text { Balance } \\
\text { eyes open }\end{array}$ & 0.149248 & 0.006592 & -0.005522 & -0.314895 & 0.201937 & 0.249226 & -0.208302 & -0.151328 & -0.346078 & 1.000000 & 0.815218 & 0.152242 \\
\hline $\begin{array}{l}\text { Balance } \\
\text { eyes } \\
\text { closed }\end{array}$ & 0.009301 & -0.052242 & 0.004239 & -0.172518 & 0.298228 & 0.131217 & -0.134117 & 0.021624 & -0.290715 & 0.815218 & 1.000000 & 0.148528 \\
\hline $\begin{array}{l}\text { Rohrer's } \\
\text { index }\end{array}$ & 0.110829 & 0.324645 & 0.201906 & -0.008992 & 0.036733 & 0.192926 & -0.844418 & 0.156256 & -0.371321 & 0.152242 & 0.148528 & 1.000000 \\
\hline
\end{tabular}

Table 6. Correlations between dependent variables in dancers at the 3rd stage of the research 
The correlation values demonstrate that the higher the flexibility, the greater one leg coordination (0.376), the lesser the strength of the lower limbs (-0.290), the smaller the body circumferences (-0.498) (Fig. 6). Both legs coordination correlates with the speed of simple reaction (0.264) and Rohrer's index (0.326), and it inversely correlates with the body height $(-0.392)$ and length measurements (-0.321), the chest width (-0.296), the body circumferences (-0.408) (Fig. 7). The better the coordination ability with one leg, the higher the level of strength and speed capabilities in a trial of 8 chené turns (0.390) and the higher the speed of simple reaction (0.265) (Fig. 8). The speed of simple reaction inversely correlates with the body height $(-0.366)$ and the body weight (-0.375) (Fig. 9). The greater the body height, the greater the strength of the lower limbs (0.399). The greater the body balance ability in a trial with open eyes, the lower the strength of the lower limbs $(-0.285)$ and the body height $(-0.290)$ (Fig. 11). The greater the body balance ability in a trial with closed eyes, the higher level of strength and speed capabilities in the trial of 8 chené turns (0.300) (Fig. 10).

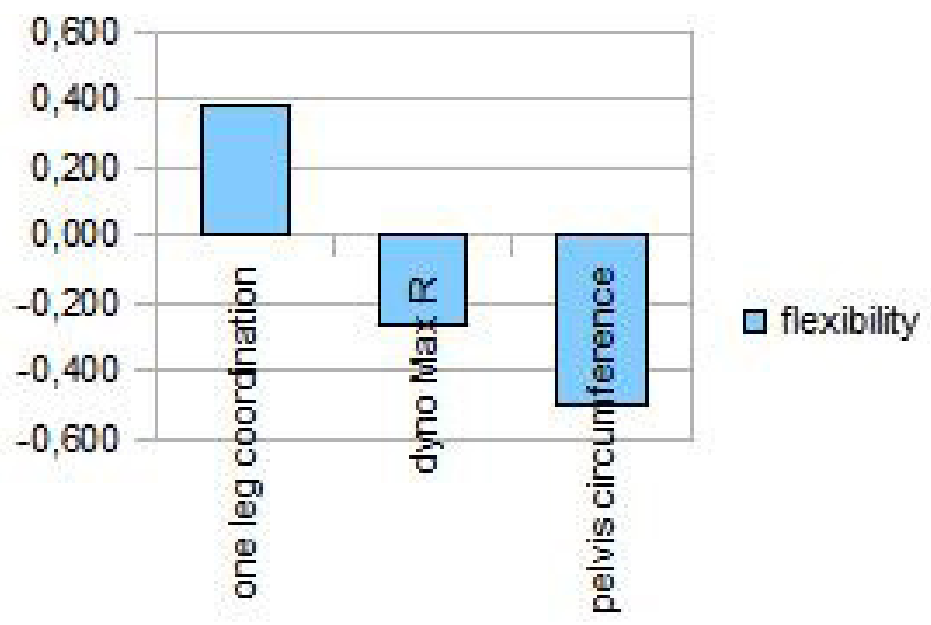

Fig 6. The correlation between flexibility and one leg coordination, dynamic strength of the lower limbs and pelvis circumference in dancers at the 3rd stage of research

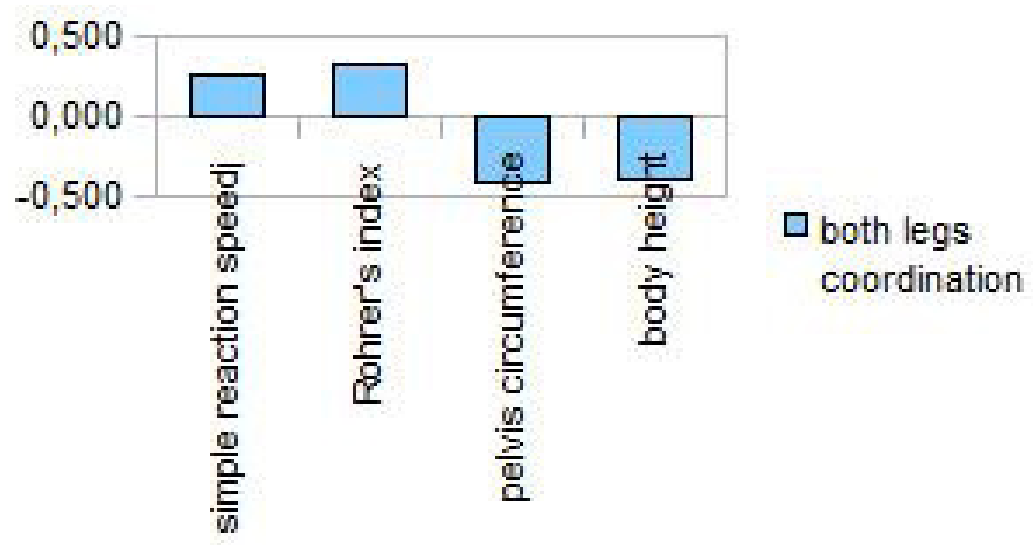

Fig 7. The correlation between both legs coordination and the simple reaction speed, Rohrer's index, the pelvis circumference and the body height in dancers at the 3rd stage of the research 


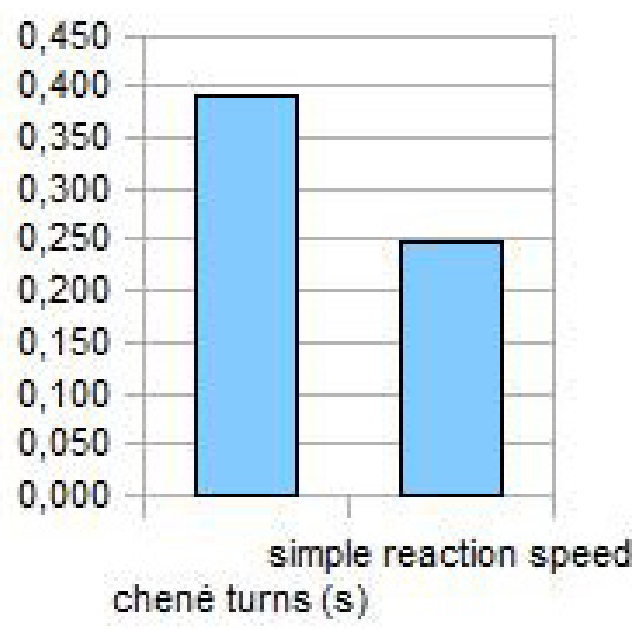

$\square$ one leg

coordination

Fig 8. The correlation between one leg coordination and technical skills and simple reaction speed in dancers at the 3 rd stage of the research

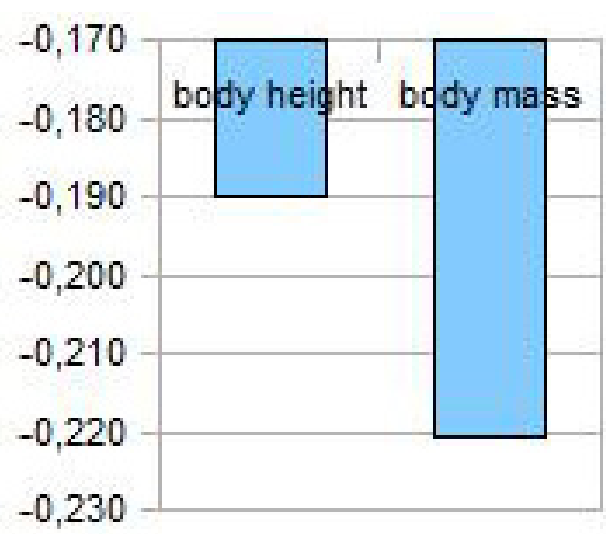

$\square$ simple reaction

speed

Fig 9. The correlation between simple reaction speed and the body height and weight in dancers at the 3 rd stage of research

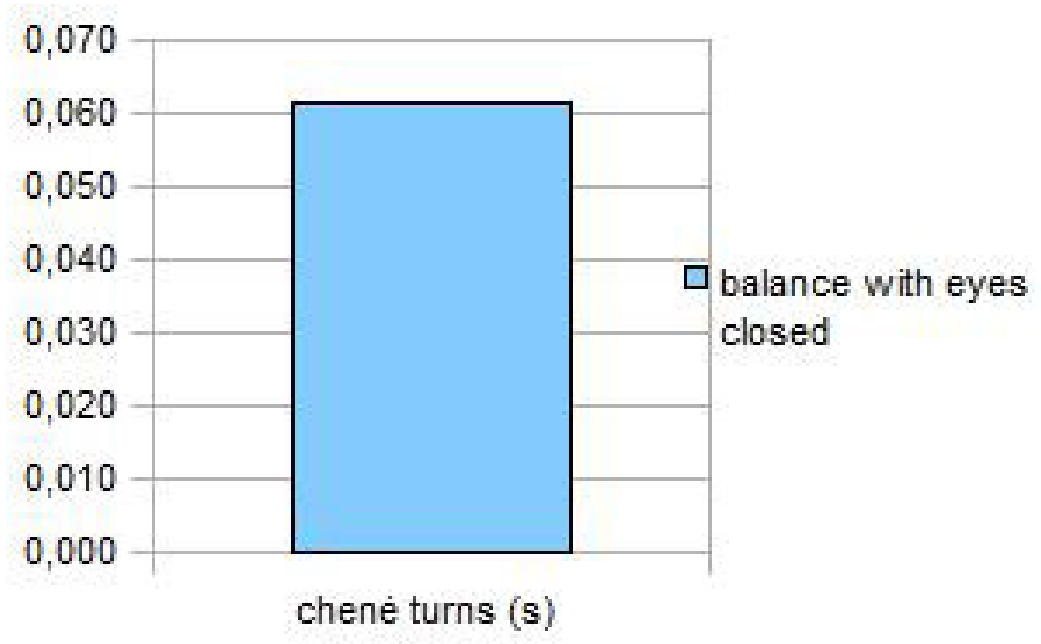

Fig 10. The correlation between balance with eyes closed and technical skills in dancers at the 3rd stage of the re-search 


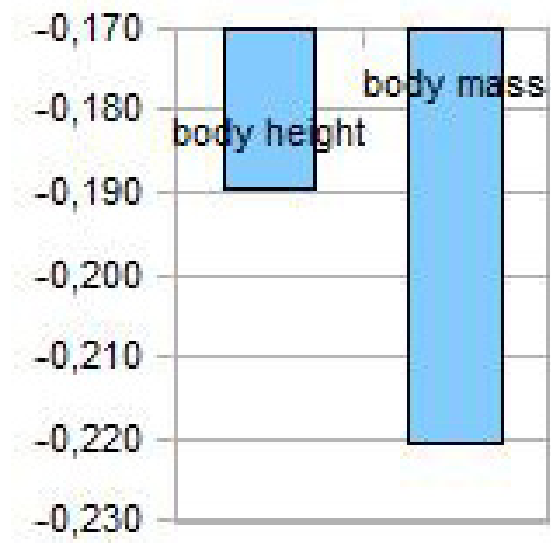

balance with eyes

open

Fig 11. The correlation between balance with eyes open and body height, body mass in dancers at the 3rd stage of the research

\section{DISCUSSION}

Results of multiple regression show that the body height and weight, the pelvis and the trunk indicators affect the sports result at the first stage of research. At the second stage the outcome is influenced by the pelvis, the trunk and the chest indicators, while at the third stage by the trunk indicator and BMI. The results of the study of correlations show that the lower the values of length, width and circumference measurements, the greater the coordination and balance abilities, which are the leading skills in dancesport. The lower the body weight, the higher the level of simple reaction speed. Dancewicz and Kruczkowski have shown in their research [7] that gymnastic exercises at the initial stage of training in artistic gymnastics do not reveal a high correlation with the body length parameters and Rohrer's index, but they also say that at the later stages of training exercises of a more complex structure are conditioned by the above parameters of the somatic composition. It can be concluded that specific dance training at later stages of training will reflect a greater correlation between sports results and the particular parameters of the somatic composition.

Multiple regression results show a significant impact of coordination on the sports outcome, especially at the first stage of research, which is confirmed by Poznanska and Banachiewicz's research [8], in which the influence of motor coordination on the sports outcome is presented. At Miletić's, Sekulić's and Wolf-Cvitak's [9] research, who examined the influence of motor abilities on the leaping performance, in seven year-old rhythmic gymnasts, we also can see the influence of coordination on the amount of the assessment. It follows from the research that the motor coordination skill in those practicing at the initial stage of training is substantially higher than in non-training persons. Similarly, according to Nowak [10] as well as Rokita and Bajdziński [6], children practicing dance are characterized by a higher level of coordination than non-training children. Also in Starosta and Karpińska's research [11] youth and adults practicing contemporary dance demonstrated a higher level of this skill in comparison to the control group. Pilewska and Sawczyn's research [12] also reveals coordination skills in dancesport dancers at a higher level than in the control group. 
Results of multiple regression showed that flexibility both at the 1 st and the 2nd stage of the study correlated with the sports outcome, while at the 3rd stage the influence of flexibility on the sports outcome was not evident. Pilewska's study [13] on dancesport competitors holding a master class shows that flexibility was at an average level. This leads to a conclusion that a high level of flexibility in the subsequent stages of dance training does not contribute to the sports outcome, as is the case in other technically complex disciplines. Flexibility is a skill whose significance and proficiency at the championship level strongly differentiates dancesport from the mentioned sports disciplines. In dancesport flexibility is needed to perform many exercises and dance figures. As in figure skating and rhythmic gymnastics it affects the general aesthetic impression [14].

In this study the results of multiple regression tests have shown that the speed and strength skills measured in a trial of 8 chené turns affect the sports outcome, and at the third stage of the research they are crucial. Results of multiple regression showed that at the initial stage of training a trial of 8 chené turns influences the sports outcome more than the trial of explosive strength of the lower limbs. However, results of other authors' studies show that both trials are important at the championship stage, where there is a specialization of couples in particular dance styles [13]. Multiple regression results for the above trial can be explained by the fact that chené turns constitute one of the important elements of the dance technique, especially at the initial stage of training, where there is no specialization in particular styles of dance. Competitors at the early stage must present both styles: Latin and standard ones.

\section{CONCLUSION}

At an early stage of training in dancesport special fitness is mostly influenced by: motor coordination, balance, flexibility, speed and strength skills, the body height and mass, the pelvis, the trunk, the chest indicators and BMI.

\section{APPLICABLE CONCLUSION}

Indicators of motor coordination measured by means of Starosta's test, of flexibility measured by a trial from IPFT, of speed and strength skills measured by 8 chené turns, of balance tested on a posturograph, of psychophysical traits tested by the speed of simple reaction and anticipation in space as well as indicators of the level of motor skills measured by means of Iowa Brace and Johnson-Metheny tests and indicators of the somatic composition best reflect the specificity of dancesport and can be recommended in the selection process in this sports discipline.

\section{REFERENCES}

[1] Fostiak D. Koordynacja ruchowa i jej znaczenie w procesie treningowym w opinii zawodnikow i trenerow sportowego tanca towarzyskiego [Motor coordination and its importance in the training process in the opinion of ballroom dancers and coaches]. Rocznik Naukowy AWF Gdansk. 1996;5:43-52. Polish.

[2] Burns AR, Gaines Ch. Sport selection. New York. (1984)

[3] Zaporozanow W, Sozanski H. Dobor i kwalifikacja do sportu [Selection and qualification for sport]. Warszawa; 1997, 7-65. Polish.

[4] Starosta W. Nowy sposob pomiaru i oceny koordynacji ruchowej [A new way of measuring and evaluat-ing motor coordination]. Monografie nr 96, AWF Poznan, 1978; 365-371. Polish.

[5] Drabik J. Testowanie sprawnosci fizycznej u dzieci, młodziezy i doroslych [Testing physical fitness in children, adolescents and adults]. Gdansk: AWF; 1997. Polish. 
[6] Rokita M, Bajdzinski M. Podstawy teorii treningu motorycznego w sportowym tancu towarzyskim [Bases of the theory of motor training in ballroom dance]. Gorzow Wielkopolski - Krakow: PTT; 2006. Polish.

[7] Dancewicz T, Kruczkowski D. Budowa somatyczna jako determinanta tempa uczenia się wybranych cwiczen gimnastycznych [Somatic composition as a determinant of the pace of learning specific gymnastic exercises]. Trening. 1999;4(44):26-32. Polish.

[8] Poznanska A, Banachiewicz D. Sprawnosc fizyczna dzieci trenujacych taniec towarzyski w krakowskich klubach tanecznych [Physical fitness of children practising ballroom dance in Krakow dance clubs]. In: Umiastowska D, editor. Aktywnosc ruchowa ludzi w roznym wieku [Physical activity of people at different ages]. Vol. 10, part 2. Szczecin, 2006. Polish.

[9] Miletic D, Sekulic D, Wolf-Cvitak J. The leaping performance of 7 year-old novice rhythmics gymnasts is highly influenced by the condition of their motor abilities. Kinesiology. 2004;36 (1):35-43.

[10] Nowak M. Wplyw zajec tanecznych na sprawnosc motoryczna dziewczat w wieku 9-11 lat [The influence of dance classes on the motor efficiency of girls aged 9-11 years]. Lider. 1994;1(36):24-26. Polish.

[11] Starosta W, Karpinska A. Ocena poziomu wybranych elementow koordynacji ruchowej u osob zajmujących się tancem wspolczesnym [An evaluation of the level of selected elements of motor coordination in people involved in contemporary dance]. In: Drozdowski S, Wojtkowiak T, editors. Wychowanie fizyczne i sport w badaniach naukowych [Physical education and sport in scientific research]. Poznań: AWF; 2002; 189-194. Polish.

[12] Pilewska W, Sawczyn S. Normatywny poziom specjalnych zdolnosci koordynacyjnych zawodnikow sportowego tanca towarzyskiego jako podstawa ich indywidualnej oceny [The normative level of special coordination skills in ballroom dancesport competitors as the basis of their individual assessment]. Rocznik Naukowy AWFiS Gdansk. 2002;12:283-291. Polish.

[13] Pilewska W. Sprawnosc fizyczna i cechy budowy somatycznej jako podstawa modelowych charakterystyk zawodniczek i zawodnikow w tancu sportowym [Physical fitness and somatic composition characteristics as a basis for model characteristics of male and female dancesport competitors]. PhD Disser-tation, AWFiS Gdansk; 2003. Polish.

[14] Starosta W, Karpinska A. Uwarunkowania rozwoju koordynacji ruchowej w tancu na podstawie wynikow badan uczennic szkol baletowych [Determinants of the development of motor coordination in dance based on studies of ballet school students]. Warszawa: Miedzynarodowe Stowarzyszenie Motoryki Sportowej, Poznan: AWF, Gorzow Wlkp: Zamiejscowy Wydział Kultury Fizycznej w Gorzowie; 2009. Polish. 